\title{
PENGEMBANGAN MEDIA PEMBELAJARAN INTERAKTIF BERBASIS KOMPUTER DALAM PEMBELAJARAN MATEMATIKA, MATERI BILANGAN PADA KELAS 3 SD
}

\author{
SYAHRONI \\ syahronijco@gmail.com \\ Program Studi Pendidikan Matematika, Fakultas Teknik, Matematika, dan IPA \\ Universitas Indraprasta PGRI \\ MAYA NURFITRIYANTI \\ Program Studi Pendidikan Matematika, Fakultas Teknik, Matematika, dan IPA \\ Universitas Indraprasta PGRI
}

\begin{abstract}
Abstrak. Penelitian ini bertujuan untuk mengetahui bagaimana pengembangan media pembelajaran kartun 3D. Metode yang dipakai metode Research and Development (penelitian dan pengembangan), tapi lebih difokuskan pada proses pengembangan menggunakan metode ADDIE. Tahapan pengembangan dalam penelitian ini diawali dengan menganalisis kebutuhan, merancang, membuat media pembelajaran kartun 3D, setalah itu di terapkan kemudian dilakukan tes kepada para ahli. Hasil penelitian menunjukkan bahwa media yang dikembangkan telah memenuhi layak dan memenuhi syarat untuk digunakan sebagai media pembelajaran kartun 3D pokok bahasan bilangan. Hal ini dilihat dari hasil validasi isi, dan kefektifan prodak oleh ahli materi sebesar $94 \%$ dinyatakan sangat baik. Untuk bahasa dan komunikasi pun mudah dipahami mendapat prosentase $91 \%$, aspek media sebesar $83 \%$, tampilan, kualitas dan keefektifan media oleh ahli desain pembelajaran sebesar 93\% dinyatakan sangat baik. Maka dapat disimpulkan bahwa media pembelajaran kartun 3D ini layak digunakan dalam pembelajaran.
\end{abstract}

Kata Kunci: Media Pembelajaran Matematika, Kartun 3D

Abstract. This study aims to find out how the development of learning media 3D cartoon. Method used Research and Development method (research and development), but more focused on development process using ADDIE method. Stages of development in this research begins by analyzing the needs, designing, creating 3D learning media cartoon, after it is applied and then tested the experts. The results showed that the media developed has met the eligible and eligible to be used as a medium of learning 3D cartoon subject matter numbers. This is seen from the results of content validation, and the effectiveness of prodak by material experts of $94 \%$ expressed very well. For languages and communications are easily understood to get $91 \%$ percentage, media aspect of $83 \%$, appearance, quality and effectiveness of media by design learning experts of $93 \%$ expressed very well. So it can be concluded that 3D learning media cartoon is feasible used in learning.

Keywords: Mathematics Learning Media, 3D Cartoon

\section{PENDAHULUAN}

Pendidikan di dunia saat ini banyak terpengaruh oleh adanya perkembangan dan penemuan- penemuan dalam bidang ilmu pengetahuan dan teknologi (IPTEK). Semakin canggih penggunaan IPTEK dalam pembelajaran, maka semakin baik pula kualitas pendidikan disuatu negara. Pengaruh perkembangan tersebut tampak jelas dalam upaya- 
upaya pembaharuan sistem pendidikan dan pembelajaran baik secara fisik seperti fasilitas pendidikan, dan sarana non fisik seperti pengembangan kualitas tenaga kependidikan. Proses pembelajaran khususnya disekolah perlu diperbaharui sesuai dengan seiringnya perkembangan pendidikan di dunia, yaitu tidak hanya belajar dengan menggunakan metode konvensional saja namun mencoba berbagai metode belajar dan didukung oleh media pembelajaran yang menambah efektifitas pembelajaran.

Salah satu ilmu dasar yang mendasari perkembangan teknologi modern adalah matematika. Untuk menguasai dan menciptakan teknologi masa depan diperlukan penguasaan matematika sejak dini. Namun pada kenyataannya matematika masih dianggap pelajaran yang sulit dan sukar dipahami oleh sebagian besar peserta didik. Hal ini senada dengan Widjajanti dan Wahyudin dalam Azizah (2016) yang mengatakan bahwa sebagian besar peserta didik menjadi malas dan kurang tertarik dalam pelajaran matematika, oleh karena itu matematika merupakan pelajaran yang sukar dan sulit, bahkan menakutkan, ditambah dengan penampilan guru matematika yang terkesan tidak bersahabat dangan peserta didik. Jika peserta didik dalam pengalaman belajarnya hanya diajarkan menggunakan sumber belajar berupa buku yang kurang menarik dan tidak adanya pengalaman baru dalam belajar matematika hal ini akan mengakibatkan peserta didik menjadi jenuh. Hal ini sesuai dengan pendapat Endah \& Leonard (2016), yang menyatakan penyelenggaraan pendidikan sudah seharusnya mampu memberikan suasana yang nyaman, aman dan mendorong peserta didik untuk senantiasa belajar guna memenuhi hasrat keingintahuannya. Untuk mengatasi hal tersebut, diperlukan sebuah inovasi pembelajaran yang efektif, efisien, dan sesuai perkembangan IPTEK hingga dapat meningkatkan aktivitas dan hasil belajar matematika siswa, salah satunya dengan menggunakan media interkatif berbasis komputer.

Pembelajaran berbasis komputer adalah suatu sistem pembelajaran yang mengahasilkan makna dengan menghubungkan muatan akademik dengan konteks teknologi. Media interaktif berbasis komputer dalam pengembangan media pembelajaran sering disebut dengan multimedia pembelajaran. Multimedia dapat memuat lebih banyak konsep materi, dapat melibatkan dua atau lebih objek (visual, audio, text, dan sebagainya), serta dapat mengemas materi menjadi lebih efektif, menarik, interaktif, dan menyenangkan. Pendidikan dan media pembelajaran memiliki kaitan yang sangat erat, proses pembelajaran tidak akan berjalan lancar tanpa adanya media pembelajaran yang tepat. Media adalah perantara atau pengantar pesan dari pemberi kepada penerima pesan. Menurut AECT, media adalah segala bentuk dan saluran yang digunakan orang untuk menyalurkan pesan atau informasi. Penggunaan media yang tepat mampu menyampaikan informasi maupun pesan yang disampaikan oleh penyampai pesan dapat diterima dengan jelas oleh penerima pesan. Begitu juga ketika media digunakan dalam proses pembelajaran di kelas, informasi yang disampaikan guru sebagai penyampai pesan di kelas dapat diterima dengan jelas oleh siswa sebagai penerima pesan di kelas.

Media belajar berbasis komputer diharapkan dapat membantu siswa belajar matematika pada tingkatan abstraksi yang berbeda karena gambar pada multimedia berperan sebagai alat mediator antara masalah pada alam nyata dengan dunia abstrak pengetahuan matematika. Penggunaan media belajar berbasis komputer dapat memudahkan guru dalam merancang alokasi waktu pembelajaran, dapat menarik minat siswa, dan pembelajaran dapat dikolaborasikan dengan semua metode belajar termasuk metode konvensional yang sering diterapkan guru saat mengajar. Selain itu media ini dapat memaksimalkan waktu belajar siswa karena siswa dapat mempelajari kembali pelajaran matematika secara mandiri menggunakan komputer yang ada dirumah. Salah 
satu software yang digunakan untuk media belajar interaktif berbasis komputer yaitu Muvizu.

Muvizu merupakan salah satu freeware atau program yang bisa diunduh gratis oleh pengguna internet. Muvizu biasa digunakan untuk mengolah kartun 3D. Muvizu memiliki banyak kelebihan diantaranya kemudahan dalam membuat objek, tokoh, latar, pencahayaan, angel kamera, pilihan warna yang banyak, gerakan serta mimik tokoh kartun yang sudah disediakan oleh muvizu. Penggunaan muvizu diharapkan siswa dapat menerima materi dengan baik. Siswa tidak hanya mendengarkan penjelasan dari guru saja siswa juga dapat melihat materi yang disampaikan dalam bentuk animasi yang dibuat semenarik mungkin. Dengan adanya media diharapkan siswa jadi senang mengikuti pelajaran dan semakin senang mempelajari mata pelajaran matematika.

Peneliti mengembangkan media pembelajaran kartun 3D berbasis muvizu untuk SD karena karakteristik belajar anak SD kelas bawah adalah meniru, mengamati, dan sangat tertarik pada kartun. Pada media pembelajaran 3D disajikan dengan cerita yang menarik, serta warna - warna yang disukai oleh anak SD, dunia anak - anak merupakan dunia yang penuh dengan permainan, anak - anak belajar sambil bermain. Anak SD sesungguhnya juga memiliki karakteristik tersendiri Pertama anak SD senang bermain, Kedua anak SD senang bergerak, dari sisi inilah penulis mencoba mengembangakan suatu kartun 3D yang didalamnya juga mengandung unsur-unsur edukatif. Tujuan dari pengembangan media pembelajaran kartun 3Dini yaitu agar anak-anak bisa lebih senang dan lebih memahami materi yang sedang dipelajarinya.

Berdasarkan latar belakang diatas peneliti menyadari betul bahwa ketersediaan media pembelajaran bagi proses pembelajaran matematika di sekolah sangatlah penting. Media belajar berbasis komputer dirasa perlu digunakan mengingat bahwa setiap siswa pasti menginginkan pembelajaran yang efektif, efisien, sekaligus menyenangkan dan sesuai dengan perkembangan IPTEK.Salah satu upaya sederhana yang dapat dilakukan peneliti untuk turut serta dalam upaya peningkatan mutu pendidikan Indonesia adalah dengan mengembangkan media belajar ini diharapkan dapat menjadi sumber mengajar guru dan sumber belajar siswa dalam pembelajaran yang berkualitas dan akan memberikan dampak positif terhadap hasil dan prestasi belajar siswa.

\section{TINJAUAN PUSTAKA}

\section{Media Pembelajaran dalam Teknologi Pendidikan}

Sukiman (2011:24) menjelaskan hal ini masuk dalam kawasan pengembangan dalam kawasan teknologi pendidikan. Pengembangan sumber belajar merupakan suatu kegiatan memfasilitasi kegiatan belajar yang harus dilakukan oleh setiap pengembang sistem pendidikan. Adapun sumber belajar belajar itu sendiri meliputi semua sumber belajar yang dapat digunakan oleh pelajar baik secara terpisah mapun dalam bentuk gabungan, untuk memberikan fasilitas belajar.

Miarso menjelaskan (2009: 544) teknologi pendidikan merupakan konsep yang komplek. Ia dapat dikaji dari berbagai segi dan kepentingan. Kecuali itu teknologi pendidikan sebagai suatu bidang kajian ilmiah, senantiasa berkembang sesuai dengan perkembangan ilmu dan teknologi yang mendukung dan mempengaruhinya. Definisi teknologi pendidikan berkembang dari tahun ke tahun.

Asosiasi Teknologi dan Komunikasi Pendidikan di Amerika, membatasi media sebagai segala bentuk dan saluran yang digunakan orang untuk menyalurkan pesan atau informasi. Dalam Sadiman (2010:6) Gagne menyatakan bahwa media adalah berbagai jenis komponen dalam lingkungan siswa yang dapat merangsangnya untuk 
belajar. Sementara itu Briggs berpendapat bahwa media adalah alat fisik yang dapat menyajikan pesan serta merangsang siswa untuk belajar. Buku, film, kaset, film bingkai adalah contoh-contohnya.

Berdasarkan pendapat-pendapat mengenai media pembelajaran berdasarkan Sadiman dan Miarso disimpulkan media pembelajaran merupakan semua alat bantu yang dipakai dalam proses pembelajaran, dengan maksud untuk menyampaikan pesan (informasi) pembelajaran dari sumber atau guru kepada penerima dalam hal ini peserta didik dan memungkinkan komunikasi antara guru dan siswa dapat berlangsung dengan baik. Pesan atau informasi yang disampaikan melalui media dalam bentuk isi atau materi pengajaran itu harus dapat diterima oleh penerima pesan dengan menggunakan salah satu atau gabungan beberapa alat indera mereka.

\section{Manfaat dan Kegunaan Media}

Menurut Sadiman (2014:17), secara umum media pendidikan mempunyai kegunaan sebagai berikut:

1) Memperjelas penyajian pesan agar tidak terlalu bersifat verbalistis (dalam bentuk kata-kata tertulis atau lisan).

2) Mengatasi keterbatasan ruang, waktu dan daya indera, seperti misalnya objek yang terlalu besar bisa digantikan dengan realita, gambar, film bingkai, film atau model. Objek yang kecil dibantu dengan proyektor mikro, film bingkai, film atau gambar. Objek gerak yang terlalu cepat atauterlalu lambat, dapat dibantu dengan timelipse atau hig-speed photography.Kejadian atau peristiwa yang terjadi di masa lalu bisa ditampilkan lagilewat rekaman film, video, film bingkai, foto maupun secara verbal. Objekyang terlalu kompleks (misalnya mesin-mesin) dapat disajikan dengan model, diagram, dan lain-lain. Konsep yang terlalu luas (gunung berapi, gempa bumi, iklim, dan lain-lain) dapat divisualkan dalam bentuk film, film bingkai, gambar dan lain-lain.

3) Penggunaan media pendidikan secara tepat dan bervariasi dapat mengatasi sikap pasif anak didik. Dalam hal ini media pendidikan berguna untuk menimbulkan kegairahan belajar, memungkinkan interaksi yang lebih langsung antara anak didik dengan lingkungan dan kenyataan, memungkinkan anak didik belajar sendiri-sendiri menurut kemampuan dan minatnya.

4) Dengan sifat yang unik pada setiap siswa ditambah lagi dengan lingkungan dan pengalaman yang berbeda, sedangkan kurikulum dan materi pendidikan ditentukan sama untuk setiap siswa, maka guru banyak mengalami kesulitan bilamana semuanya itu harus diatasi sendiri. Hal ini akan lebih sulit bila latar belakang lingkungan guru dengan siswa juga berbeda. Masalah ini dapat diatasi dengan media pendidikan, yaitu dengan kemampuannya dalam memberikan perangsang yang sama, mempersamakan pengalaman dan menimbulkan persepsi yang sama.

\section{Hakikat Pembelajaran Matematika}

Mata pelajaran matematika termasuk ke dalam kelompok mata pelajaran Ilmu Pengetahuan dan Teknologi yang memiliki karakteristik. Pembelajaran matematika berfungsi untuk mengembangkan kemampuan komunikasi, ide, gagasan.serta bahasa melalui model matematika yang dapat berupa kalimat dan persamaan matematika, diagram, grafik atau tabel. Menurut Departemen Pendidikan Nasional (2004) matematika berfungsi mengembangkan kemampuan menghitung, mengukur, menurunkan dan menggunakan rumus matematika yang diperlukan dalam kehidupan sehari-hari. Tujuan pembelajaran matematika adalah: 
a) Melatih cara berfikir dan bernalar dalam menarik kesimpulan. Misalnya melalui kegiatan penyelidikan, eksplorasi, eksperimen, menunjukan kesamaan, perbedaan, konsisten dan inkonsistensi.

b) Mengembangkan aktivitas kreatif yang melibatkan imajinasi intuisi dan penemuan dengan mengembangkan pemikiran divergen, orisinil, rasa ingin tahu, membuat prediksi dan dugaan serta mencoba-coba.

c) Mengembangkan kemapuan pemecahan masalah.

d) Mengembangkan kemampuan informasi atau mengkomunikasikan gagasan antara lainmelalui pembicaraan lisan, catatan, grafik, peta, diagram dalam menjelaskan gagasan.

Menurut Dienes dalam Kristiyanto (2007) pembelajaran matematika dapat dicapai melalui pola berkelanjutan yang setiap seri dalam rangkaian kegiatan belajarnya berjalan dari yang konkret ke simbolik. Tahap belajar adalah interaksi yang direncanakan antara satu segmen struktur pengetahuan dan belajar aktif, yang dilakukan melalui media matematika yang didesain secara khusus. Menurut Dienes, permainan matematika sangat penting sebab operasi matematika dalam permainan tersebut menunjukkan aturan secara konkret dan lebih membimbing dan memahami pengertian matematika pada peserta didik.

Menurut Skemp dalam (Widyastuti: 2014), peserta didik belajar matematika melalui dua tahap yaitu tahap konkret dan tahap abstrak. Pada tahap pertama, yaitu tahap konkret, peserta didik memanipulasi benda-benda konkret untuk menghayati ide-ide abstrak. Pengalaman awal berinteraksi dengan benda konkret ini akan membentuk dasar bagi pembelajaran selanjutnya, yaitu tahap abstrak atau tahap kedua. Agar pembelajaran berguna bagi peserta didik, sifat-sifat umum dari pengalaman peserta didik harus dipadukan untuk membentuk suatu struktur konseptual atau suatu skema. Dengan demikian, guru hendaknya memberikan kegiatan kepada peserta didik untuk menyusun struktur matematika sedemikian rupa agar peserta didik mengerti sebelum mereka dapat menggunakan pengetahuan awalnya sebagai dasar untuk belajar pada tahap berikutnya, atau menggunakan pengetahuan mereka secara efektif untuk menyelesaikan masalah.

\section{Definisi Kartun 3D}

Kartun (cartoon dalam Bahasa Inggris) berasal dari bahasa Italia, cartone, yang berarti kertas. Kartun adalah lukisan tentang peristiwa-peristiwa harian yang digambarkan secara menyenangkan/menarik. Kartun pada mulanya adalah penamaan bagi sketsa pada kertas alot (stout paper) sebagai rancangan atau desain untuk lukisan kanvas atau lukisan dinding, gambar arsitektur, motif permadani, atau untuk gambar pada mozaik dan kaca. Namun seiring perkembangan waktu, pengertian kartun pada saat ini tidak sekadar sebagai sebuah gambar rancangan, tetapi kemudian berkembang menjadi gambar yang bersifat dan bertujuan humor dan satir.Sebagai salah satu bentuk komunikasi grafis, kartun merupakan suatugambar interpretatif yang menggunakan simbol-simbol untuk menyampaikan suatu pesan secara cepat dan ringkas, atau sesuatu sikap terhadap orang, situasi, atau kejadian-kejadian tertentu. Kartun biasanya hanya mengungkap esensi pesan yang harus disampaikan dan menuangkannya ke dalam gambar sederhana, tanpa detail, dengan menggunakan simbol-simbol, serta karakter yang mudah dikenal dan dimengerti secara cepat.

Kartun mempunyai sisi menarik yang memiliki keunggulan lebih dibandingkan dengan media komunikasi yang lain. Ketertarikan seseorang terhadap kartun menurut penelitian Priyanto Sunarto yang berjudul Metafora Visual Kartun Editorial pada Surat Kabar Jakarta 1950-1957 disebabkan dalam mengungkapkan komentar, kartun menampilkan masalah tidak secara harfiah tetapi melalui 
metafora agar terungkap makna yang tersirat di balik peristiwa. Metafora merupakan pengalihan sebuah simbol (topik) ke sistem simbol lain (kendaraan). Penggabungan dua makna kata/situasi menimbulkan konflik antara persamaan dan perbedaan, hingga terjadi perluasan makna menjadi makna baru. Ketertarikan seseorang terhadap kartun dibandingkan dengan media yang lain juga dikarenakan simbol-simbol tertentu dalam kartun yang menyebabkan kelucuan, selain itu isi kartun di media massa menceriterakan kehidupan sehari-hari.

\section{METODE}

Sesuai dengan tujuan penelitian, metode pengembangan disesuaikan dengan kegiatan penelitian yang dilakukan. Metode penelitian mengacu pada pengembangan ADDIE yang muncul pada tahun 1990-an yang dikembangkan oleh Reiser (2001) dan Mollenda (2003).Salah satu fungsinya ADDIE yaitu menjadi pedoman dalam membangun perangkat dan infrastruktur program pelatihan yang efektif, dinamis dan mendukung kinerja pelatihan itu sendiri. Model pengembangan yang melalui lima tahap, yaitu analisis, design, pengembangan, implementasi, dan evaluasi.Dalam penggunaannya model pengembangan ADDIE dianggap berurutan tetapi juga interaktif dimana hasil evaluasi setiap tahap dapat membawa pengembangan pembelajaran ke tahap sebelumnya. Adapun langkah-langkahnya sebagai berikut tahap analisis, dalam tahap ini terdapat beberapa kegiatan diantaranya (analisis pasar,analisis pengguna, analisis kurikulum,analisis media, dan analisis sarana). Yang kedua adalah tahap desain, hasil analisis digunakan untuk acuan dalam penyusunan suatu kerangka isi program media pembelajaran. Kerangka isi program untuk menggambarkan keseluruhan isi materi yang tercangkup dalam penulisan garis besar isi media dan penyusunan naskah. Selanjutnya yaitu tahap pengembangan, Tahap produksi ini adalah mengubah naskah menjadi sebuah program yang berisi teks, suara, gambar, animasi. Hal ini adalah sebuah produk media pembelajaran kartun 3D. Sebelum dilakukannya penerapan langsung dalam pembelajaran program media pembelajaran kartun 3D di cek dan di validasi. Yang keempat adalah tahap implementasi, produk pembelajaran yang telah selesai dibuat dan diuji cobakan kepada beberapa ahli yang terdiri dari ahli materi, ahli media, ahli bahasa, dan ahli desain pembelajaran matematika. Dan yang terakhir tahap evaluasi Revisi produk dilakukan, apabila ada masukan dari para ahli. Dalam tahap ini peneliti selalu mengevaluasi kinerja produk dalam hal program media pembelajaran kartun 3D untuk mengetahui kelemahan-kelemahan yang ada.

\section{HASIL DAN PEMBAHASAN}

Pengembangan media pembelajaran kartun 3D yang telah dilaksanakan oleh peneliti menggunakan acuan model pengembangan produk ADDIE (Analize, Design, Development, Implementation, Evaluation) Keunggulan model ADDIE yaitu dilihat dari prosedur kerjanya yang sistematik yakni pada setiap langkah yang akan dilalui selalu mengacu pada langkah sebelumnya yang sudah diperbaiki sehingga diperoleh produk yang efektif.Dari penelitian ini dihasilkan sebuah media pembelajaran yang diharapkan mampu menimbulkan semangat belajar siswa dan rasa ingin tahu yang tinggi. Sehingga siswa dapat belajar matematika dengan lebih asyik dan menyenangkan. Adapun isi dari media yang dihasilkan adalah sebagai berikut:

Tahapan analisis kebutuhan mendasari dalam membuat sebuah program atau media. Tujuan dilakukannya analisis adalah untuk mendapatkan data pendukung pengembangan media. Analisis kebutuhan dilakukan peneliti pada saat observasi awal penelitian. Selanjutnya adalah tahapan desain pengembangan, pembuatan desain didasarkan pada hasil observasi awal dalam kegiatan analisis kebutuhan dimana 
meliputi penyusunan peta materi, penyusunan GBIM, penyusunan naskah dan desain tampilan. Rancangan mediapembelajaran untuk pembelajaran matematika ini masih bersifat konseptual dan akan mendasari proses pengembangan berikutnya.

Tahap produksi ini adalah mengubah naskah menjadi sebuah program yang berisi teks, suara, gambar, animasi. Dalam hal ini program adalah sebuah produk mediapembelajaran kartun 3D. Sebelum dilakukannya penerapan langsung dalam pembelajaran program media pembelajaran kartun 3D di cek dan di validasi.Proses produksi media pembelajaran kartun 3D dibagi menjadi tiga tahap yaitu pra produksi, produksi dan pasca produksi.

1) Pra Produksi

Tahap ini dimulai dengan mempersiapkan bahan-bahan yang digunakan untuk memproduksi produk multimedia pembelajaran interaktif. Berikut merupakan bahan-bahan yang dibutuhkan dalam proses produksi komputer/laptop, Software Muvizu, mikrophone,software pendukung seperti Movie Maker (editing video), Cool Edit Pro (Editing suara), Audacity (rekaman suara) dan naskah media pembelajaran kartun 3D.Persiapan dimulai dengan mendownload Muvizu pada web resmi www.muvizu.com kemudian menginstalnya ke dalam komputer/laptop. Setelah software utama telah selesai terinstal, kemudian dilanjutkan software pendukung untuk menambah tampilan lebih menarik.

2) Produksi

Pada tahap ini mulai dilakukan produksi dengan berpedoman pada naskah media pembelajaran kartun 3D yang sudah jadi. Pembuatan di mulai dengan memilih karakter animasi kartun sesuai dengan karakter tokoh pada cerita. Karena karakter yang di sediakan oleh Muvizu tidak semuanya sesuai dengan cerita maka karakter di edit sesuai dengan karakter tokoh yang ada dalam cerita. Properti dan setting background di sesuiakan dengan ide cerita untuk menunjang tercapainya cerita. Setelah tokoh, properti, dan background selesai dibuat,langkah selanjutnyaadalah menganimasikan gambar yang telah dibuat tadi mengikuti alur cerita pada naskah. Tahap selanjutnya adalah melakukan pengisian suara untuk tiap karakter mengikuti naskah menggunakan software Audacity. Audacity memudahkan dalam pengisian suara dan pengeditan suara melalui tool effect yang dapat menggantisuara sesuai dengan karakter tokoh. Setelah suara semuanya terkumpul, suara di gabungkan dengan software cool edit pro dan merendernya untuk menjadi file mp3. File yang sudah jadi tersebut di masukan kedalam file Muvizu di sesuaikan dengan dialog yang dilakuakan.Ketika animasi mentah telah selesai, langkah selanjutnya adalah mengekspor (render) animasi ke dalam format.avi agar dapat dibaca oleh windows. Langkah-langkah di atas diterapkan untuk setiap scene sesuai naskah. Potongan-potongan kartun animasi yang telah jadi lalu digabung dan dikombinasikan dengan backsound serta efek suara menggunakan software Movie Maker. Pada tahap ini pula dilakukan editing dan koreksi terhadap kartun animasi sebelum diekspor menjadi kartun 3D yang utuh.

3) Pasca Produksi

Tahap dimana animasi media pembelajaran kartun 3D yang sudah jadi disalin ke Drive penyimpanan seperti $\mathrm{CD}$, Flasdisk, dan jenis penyimpanan data lainnya, agar mudah digunakan pada perangkat keras yang tersedia di lapangan seperti VCD player, DVD Player, komputer, maupun laptop. Dan juga produk akan diunggah ke jejaring sosial seperti youtube ataupun facebook, hal ini agar disaksikan kapan pun dan dimana pun oleh pengguna smartphone sehingga peserta didik dapat mempelajarinya tidak harus di sekolah. 
Selanjutnya tahap implementasi dimana tahap ini adalah melakukan uji angket produk diujikan kepada uji ahli media, uji ahli desain, uji ahli bahasa, dan uji ahli materi. Hasilnya adalah ada beberapa hal yang perlu direvisi, yaitu Suara backsound terlalu keras, pada penjumlahan ada contoh yang tidak bisa dijumlahkan karena berbeda variabel, untuk gambar ilustrasi sebaiknya benda yang lebih dekat dengan anak,sebaiknya dilengkapi dengan evaluasi berupa soal untuk mrngetahui pemahaman anak, Tambahkan dengan kompetensi dasar yang menunjang dengan isi/materi, untuk penjumlahan dan pengurangan ditambahkan contoh dengan gambar blok diens.

Pada proses akhir ini, berdasarkan hasil angket dari para ahli. Pada tahap ini, media yang sudah di uji oleh para ahli untuk selanjutnya akan diteruskan dan diperbaiki sesuai dengan masukan masukan para ahli tersebut. Sehingga tampilan media sebagai berikut:

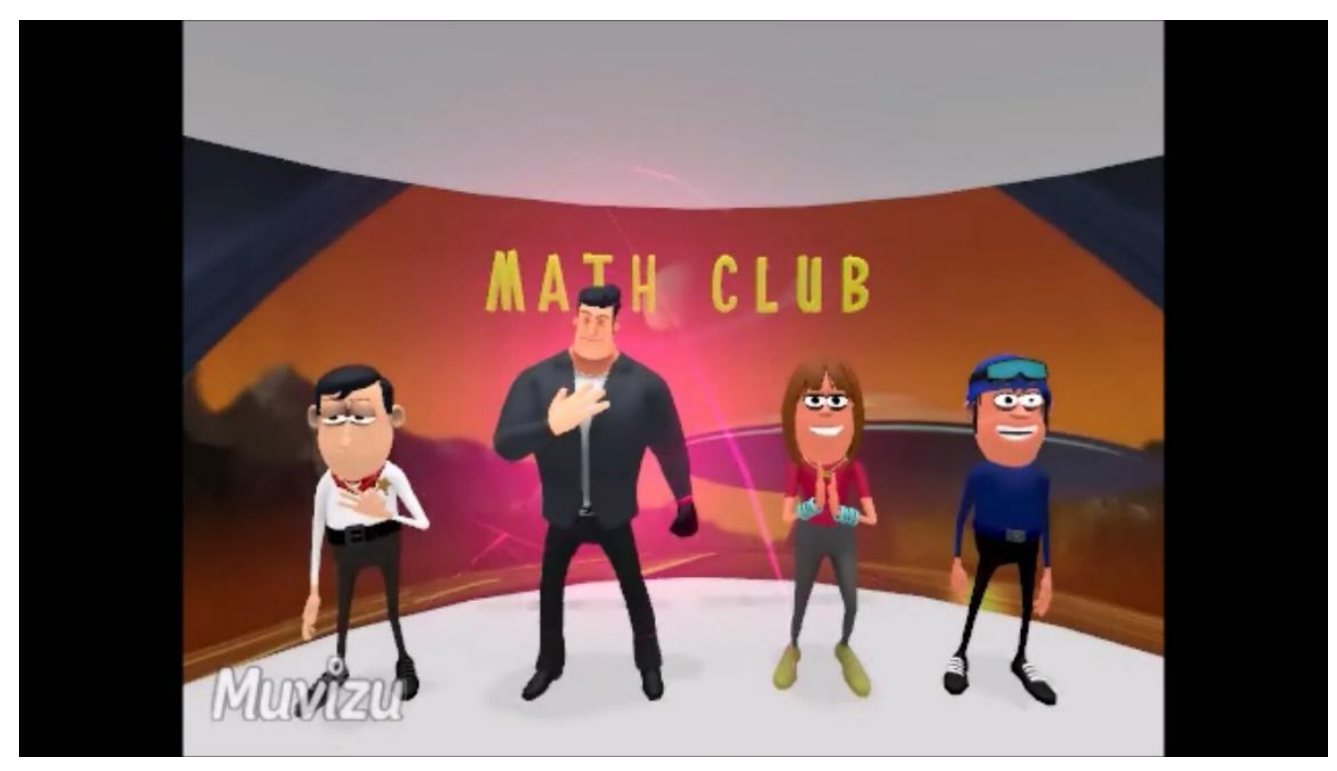

Gambar 1. Hasil tampilan media

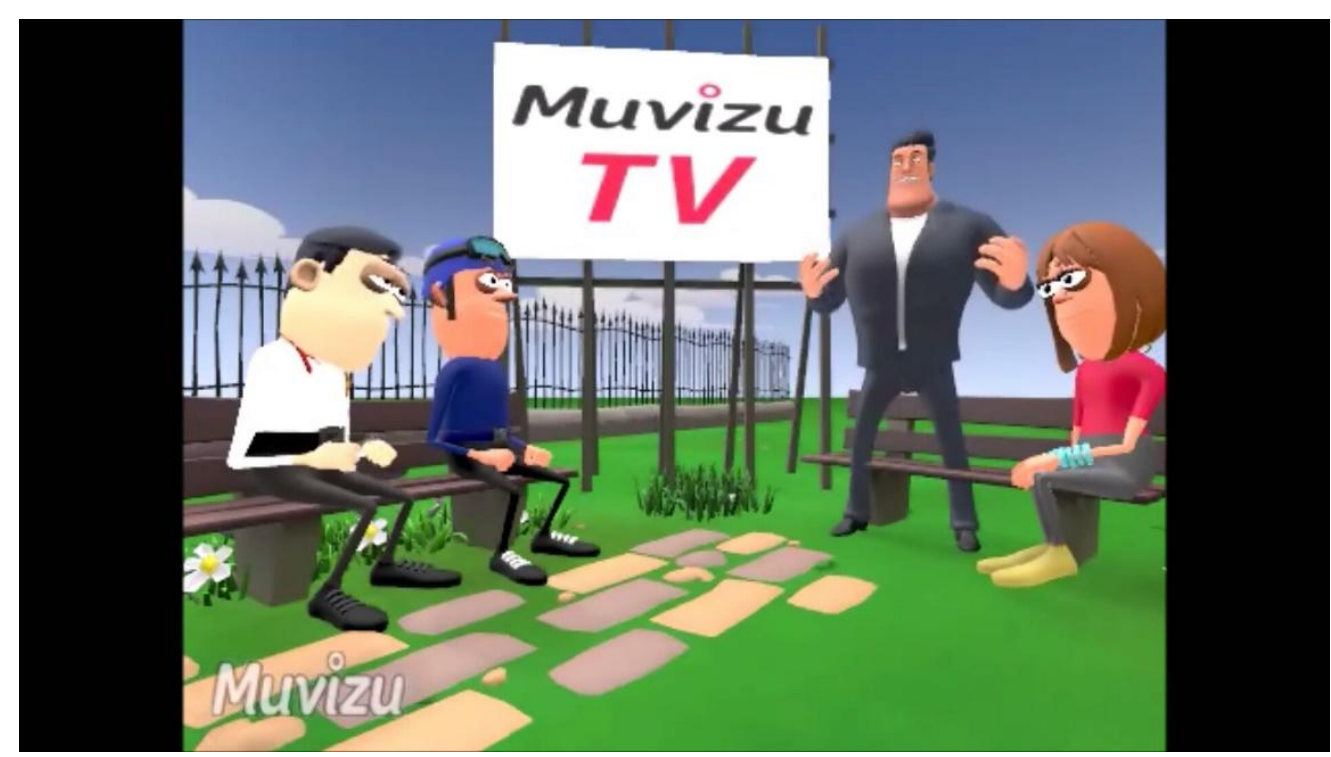

Gambar 2. Hasil tampilan media 


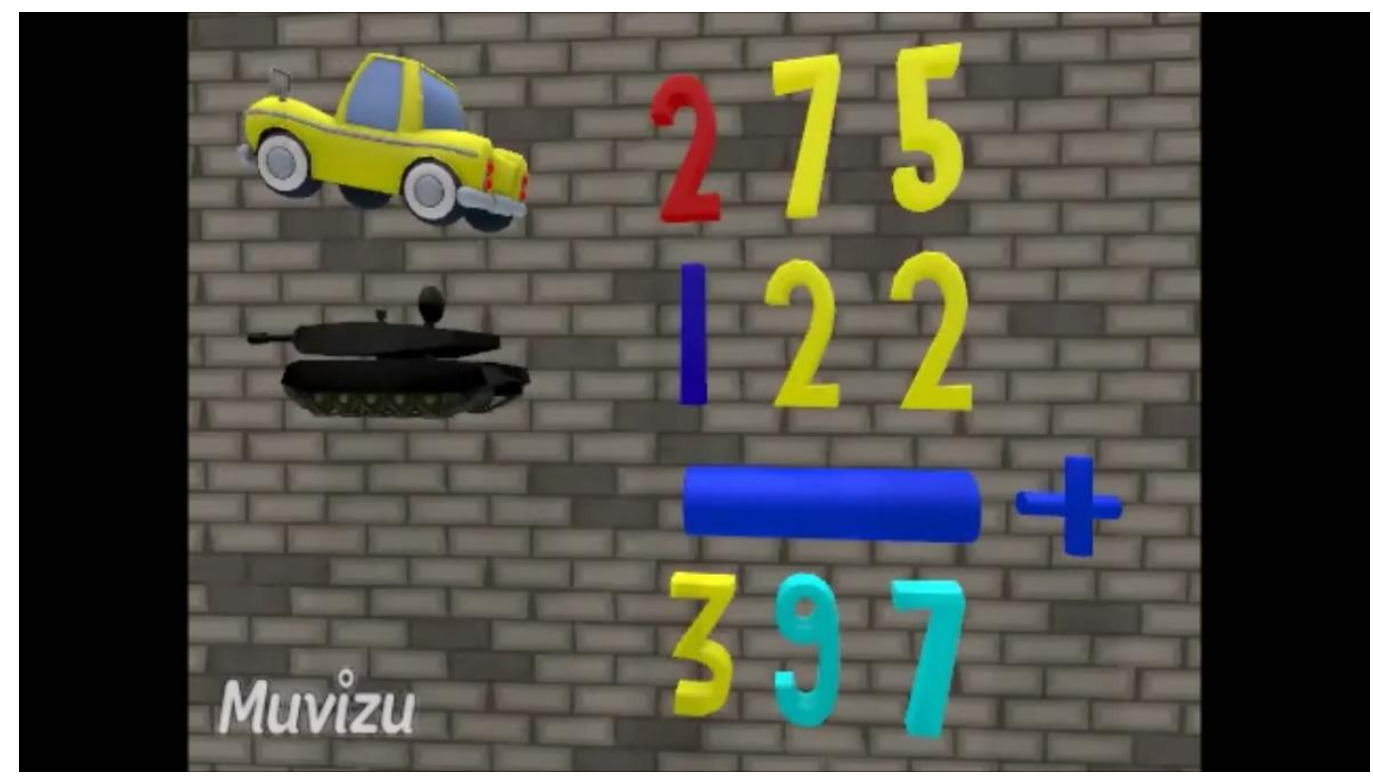

Gambar 3. Hasil tampilan media

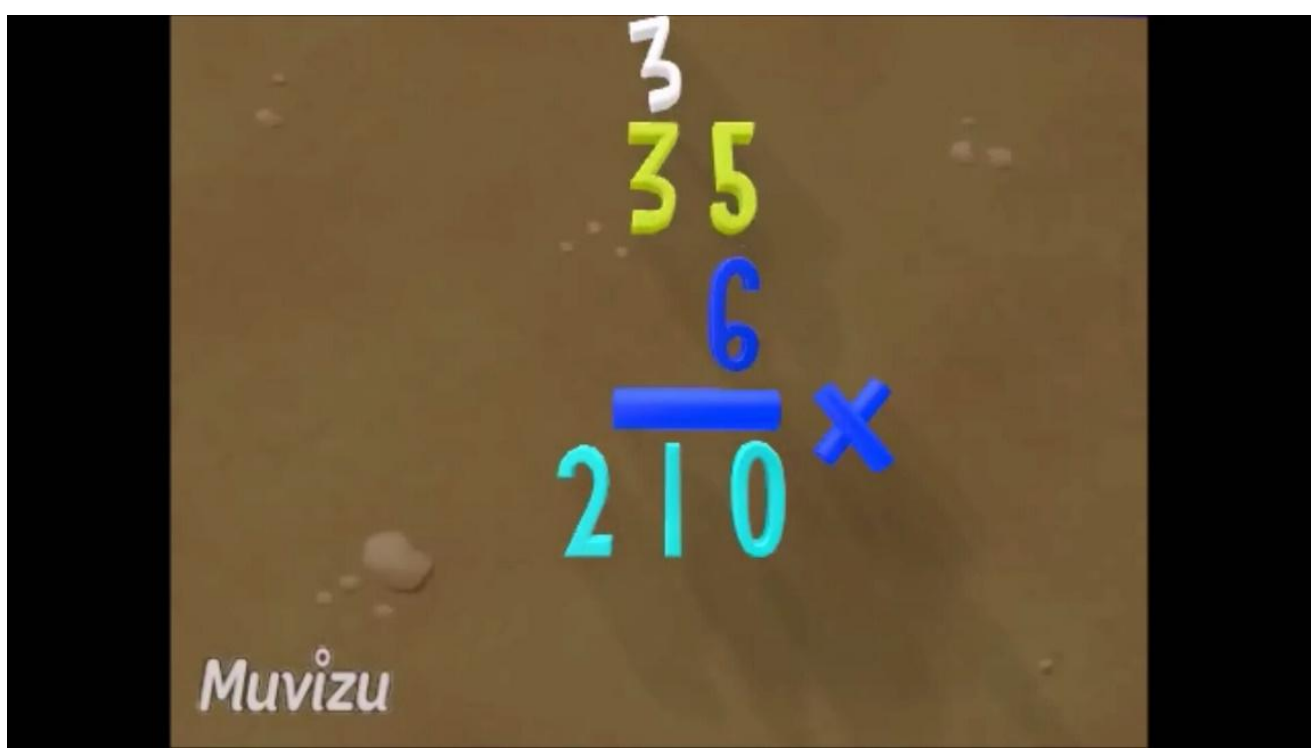

Gambar 4. Hasil tampilan media

\section{PENUTUP}

Berdasarkan analisis dan pembahasan, maka dapat disimpulkan bahwa penelitian pengembangan media berbasis komputer pada pembelajaran matematika kelas III SD dalam bentuk audiovisual dengan menggunakan softwaremuvizu atas pokok bahasan bilangan yang dilakukan di SDN Ragunan 07, Jakarta Selatan layak dipakai sebagai penunjang pembelajaran matematika. Hal ini berdasarkan pada hasil uji ahli Bahasa, ahli desain, ahli media, dan ahli materi. Pada hasil uji coba ahli Bahasa, media dinyatakan baik karena teks penjelasan dalam media mudah dipahami dengan prosentase $91 \%$. Sedangkan uji ahli desain pembelajaran matematika menyatakan media baik dengan 
prosentase $93 \%$. Sedangkan uji ahli media pembelajaran matematika menyatakan media baik dengan prosentase $83 \%$. Sedangkan uji ahli materi pembelajaran matematika menyatakan media baik dengan prosentase $94 \%$.

Adapun beberapa saran yang dapat dijadikan pertimbangan antara lain:

1. Perlunya penggunaan media pembelajaran kartun 3D dalam prosespembelajaran di sekolah sebagai alternative media pembelajaran untuk mengatasi permasalahan dalam proses belajar seperti kurangnya perhatian siswa dalam belajar, siswa kurang semangat dalam mengikuti pelajaran,materi pelajaran yang abstrak, ketakutan siswa pada mata pelajaran tersebut. Sehingga pembelajaran dapat berjalan lancar, tujuan pembelajaran tercapai dan siswa memahami pelajaran dengan baik.

2. Setelah dikembangkan, maka media pembelajaran kartun 3D ini perlu diujilebih lanjut untuk mengetahui apakah media pembelajaran kartun 3D inidapat dikembangkan untuk materi dan mata pelajaran yang lain atau tidak.

3. Guru hendaknya membekali dirinya lebih baik lagi dalam memanfaatkan dan mengembangkan media pembelajaran agar suasana belajar lebihmenyenangkan tanpa mengurangi esensi dari materi pelajaran yang sedangdisampaikan.

\section{DAFTAR PUSTAKA}

Azizah, S. 2016. Pengembangan media pembelajaran matematika berbasis Muvizu di kelas 2 Sekolah Dasar. JKPM, 1, 180-192.

Arsyad, A. 2002. Media Pembelajaran. Jakarta: Raja Grafindo Persada.

Astuti, T. 2013. Pengembangan Media Pembelajaran Kartun 3D Berbasis Muvizu Pada Mata Pelajaran Matematika Kelas I Di SD Lab School UNNES. Semarang: Universitas Negeri Semarang.

Brinka. 2012. Penggunaan Media Kartun Dalam Pembelajaran Matematika. Diambil kembali dari Blogspot.co.id: http://kuliahvsngebolang.blogspot.co.id/2012/05/ penggunaan-media-kartun.html

Endah, A. K., \& Leonard, L. 2016. Pengembangan desain pembelajaran matematika akselerasi tingkat SD berbasis bakat dan minat. In Seminar Nasional Pendidikan Matematika (pp. 163-173). Jakarta: Unindra Press.

Harryningsih. 2010. Fungsi Media Pembelajaran. Diambil kembali dari wordpress.com: https://sriharryningsih.wordpress.com/2010/10/11/fungsi-media-pembelajaran/

Kristiyanto. 2007. Math Education. Diambil kembali dari blogspot.co.id: http://kris21.blogspot.co.id/search?q=pembelajaran+matematika

Miarso, Y. 2009. Menyemai Benih Teknologi Pendidikan. Jakarta: Kencana Prenada Media Group.

Sadiman, A. 2014. Media Pendidikan. Jakarta: Rajawali Pers.

Sukiman. 2012. Pengembangan Media Pembelajaran. Yogyakarta: Pedagogia. 